\title{
Restoring trustworthiness in the financial system: Norms, behaviour, and governance
}

\section{AISLING CREAN, NATALIE GOLD, DAVID VINES and ANNIE WILLIAMSON}

Abstract: We examine how trustworthy behaviour can be achieved in the financial sector. The task is to ensure that firms are motivated to pursue the long-term interests of customers rather than pursuing short-term profits. Firms' self-interested pursuit of reputation, combined with regulation, is often not sufficient to ensure that this happens. We argue that trustworthy behaviour requires that at least some actors show a concern for the well-being of clients, or a respect for imposed standards, and that the behaviour of these actors is copied in such a way that it becomes a behavioural norm. We briefly suggest what such behavioural norms might need to be if trustworthy behaviour is to be achieved, and consider how they might be supported; we describe the research that is necessary in order to understand these norms in more detail. We argue that the norms of traders are different from the norms of those engaged in other activities, since they are inevitably self-interested, and we consider the risk that traders' norms might undermine those of other actors. We analyse the task for governance in dealing with this problem, and the role which leadership by a corporate board and management might play in doing this. We describe the need for further research to describe how this might be done.

Keywords: Corporate governance, finance, norms, other-regarding behaviour, non-selfish motivation, trust, trustworthiness, short-termism.

\section{EXECUTIVE SUMMARY}

The global financial crisis revealed how untrustworthy the financial sector is, and subsequent studies indicate there has been little meaningful reform since. This paper considers how trustworthiness may be restored through the framing of non-selfregarding behavioural norms which improve the culture of the financial system.

The task is to ensure that firms are motivated to pursue the long-term interests of customers rather than pursuing short-term profits. Trustworthiness requires reliable 
competence and honesty - a commitment to tell the truth and keep promises. Trustworthy behaviour must be understood and supported in such a way that it becomes a norm - a self-reinforcing pattern within a group.

The authors consider four types of financial activity: mortgage lenders and their advisors, fund managers, insurers, and traders, examining the different motivations, standards, and norms of each, and assessing how trustworthiness through non-selfinterested behaviour may be advanced.

For the first three groups, they suggest two necessary steps. First, that enough people realise the importance of acting in a way which has regard to the needs of customers. Second, that others need to copy the behaviour to ensure it becomes a norm.

The norms of traders, the fourth group, are different, since traders are inevitably self-interested. Unlike the other front-line employees analysed, norms that show concern for others are inappropriate. Indeed, there is a risk that traders' norms might undermine those of other actors. Traders have a narrowly defined set of obligations. They are expected to comply with these and avoid fraud.

Such differing norms, often within a single company, pose complex and testing governance questions for both boards and management. Financial institutions invariably have multiple corporate purposes that may include competing and even conflicting services to different types of client and shareholder. Each require different norms for trustworthy behaviour and these need to be sustained by unique motivations, or standards.

The boards of trustworthy companies will work to ensure the longer term prosperity of the firm. With their unique oversight of corporate strategy and operations, they will need to show strong leadership, finding ways of defending themselves against the pressure exerted by transactional shareholders, so as to encourage the behaviour of trustworthy employees.

The paper describes specific areas of research which are required to understand how trustworthy behaviour can be made to happen, including how self-interested motivations can be prevented from infecting motivations in other parts of the institution, and how to protect customers in client-facing units from trading activity within the same firm that might damage their well-being.

The authors conclude by noting that efforts to achieve trustworthiness have implications for the proposed ring fencing of banks into retail and investment entities. Trading departments in which employees are necessarily profit-seeking and selfinterested should also be separated. The more complex and ambiguous the structure of a firm, the harder but more important such reform and restructuring will be to achieve, posing a clear challenge to those working on ethics management in finance, and ethical leadership. 


\section{INTRODUCTION: TRUSTWORTHINESS IN FINANCE}

The global financial crisis revealed how untrustworthy the financial sector is. Trust in financial leaders is low (Edelman 2018), with more people distrusting than trusting these leaders: net trust in financial leaders (the percentage who say that they trust leaders minus the percentage who say that they do not trust them) is -21 (Ipsos MORI 2017). Despite firms and governments taking steps to reform the industry (e.g., Barclays Bank 2013, House of Lords, House of Commons 2013, G30 2015), it is generally thought that further reform is necessary. This paper is about how trustworthiness might be restored, and about the research which is needed to underpin a move in that direction.

In our view, two things are necessary. First, we think that trustworthiness will only return when the behaviour of those who work in the financial sector is underpinned by what we call non-self-regarding motivations. This includes motivations which are concerned with the well-being of clients and customers and motivations to do the right thing or follow correct procedures (Gold 2014). It appears that, in the period running up to the financial crisis, many of those working in the financial system became entirely self-regarding and selfish; showing a concern for the personal rewards which could be made rather than a concern for the outcomes for clients and customers. The papers brought together in Morris and Vines (2014) suggested that we need to find a way to reverse this. Second, it is rightly argued that not all of those who work in the financial system have, or can have, non-self-regarding motivations, and that outcomes will also depend on the behaviour of these other people. This paper goes beyond the papers presented in Morris and Vines (2014) by discussing the way in which the behaviour of non-self-regarding actors can be copied by others, so that norms of behaviour emerge which have regard for the well-being of customers and clients. These two points, taken together, can lead to an understanding of how to reform the culture of the financial system.

There is, at present, rather little evidence on how motivations are formed, or on how the copying of the behaviour of those who lead by those who follow actually takes place, and on how leadership might influence these norms. In this paper we discuss the work which is needed to provide that evidence.

We also argue that the norms of traders are different from the norms of those engaged in other activities, in that traders are inevitably self-interested, and we consider the risk that traders' norms might undermine those of other actors. We analyse the task for governance in dealing with this problem, and the role which leadership by a corporate board, and management, might play in doing this. We describe the need for further research to describe how this might be done. 


\section{SELF-INTEREST, OTHER-REGARDING OBLIGATIONS, FRAMING, AND NORMS}

Trust needs to be distinguished from trustworthiness. Many people put their trust in Bernie Madoff, but he was not trustworthy. Trustworthiness requires one to be competent and honest, and reliably so (O'Neill 2002). Some researchers have argued that the global financial crisis was mainly the result of incompetence (de Bruin 2015) and it is clear that institutional and individual incompetence was pervasive. But there are also problems of honesty. The solution to those problems requires that actors be prepared to reveal information, to tell the truth, and to keep promises, and that they be prepared to do so reliably. It is these issues which we address here.

The standard way of analysing trustworthiness in financial markets builds on traditional economists' assumptions that firms set out to maximise profits and that employees are self-regarding and selfish: that is, motivated by the financial reward that they receive rather than by a conception of service to the public good. If this is so, then a temptation will inevitably arise - as it did in extreme in the case of Madoff - to pursue returns at the expense of clients. The conventional argument is that, nevertheless, trustworthiness is likely to be achieved because firms, employees, and customers have long-term relationships (they are involved in 'repeated games') and that actors have an incentive to acquire a reputation for trustworthy behaviour (Mailath \& Samuelson 2006). However, as is argued in Gold (2014) and Jaffer et al. (2014), the pursuit of reputation by self-interested actors is not sufficient to solve these problems. There are three reasons that firms, and the individuals within them, might not act in the interests of clients even when a reputation is being pursued: 'incompleteness' of contracts, that is, the fact that it is not possible to contract for every contingency (Williamson 1993); the impossibility of designing incentives that reliably promote desirable behaviour when information can be concealed (Noe \& Young 2014); and the 'backwards induction problem', which can lead trustworthy behaviour based on reputation to unravel if actors know that there will be an incentive to be untrustworthy some time in the future (Hollis 1998).

Trustworthiness particularly matters in finance. Since savings and investment are both long-term activities, in which savers and investors have far less information than the firms with which they deal, there is a particular need for financial firms to be seen to be trustworthy. In this paper we will focus on one particular possible lack of trustworthiness in the process of financial intermediation: namely, the pursuit of short-term returns by those who work for financial institutions, and the institutions themselves, at the expense of those to whom they provide financial services. As recent experience has shown, such pursuit can lead financial employees to exploit incomplete contracts and information asymmetries or to act badly now because they believe that such 
behaviour will become common in the future. Examples, which we will discuss, include: (i) seeking short-term return from lending to overly risky borrowers, (ii) imposing harm on customers as a result of privileged information about difficulties likely to emerge in the future, and (iii) encouraging clients to pay now for insurance protection which is unlikely to benefit them in the future. There are other possibilities; for an extended discussion, see Jaffer et al. (2014) and Noe and Young (2014). Our paper will focus on ways of ensuring that financial firms are trustworthy, in that they do not do these things.

There is a large literature in psychology, and now in behavioural economics, which shows that human motivations are more varied than is assumed by economists, something which has now been taken up by behavioural economics. And philosophers generally agree that trustworthy behaviour cannot simply involve the pursuit of reputation by those seeking profit or financial incentives, but must involve some non-self-regarding motivations (Baier 1986, Holton 1994).

Gold (2014) introduced the term 'strong trust' to identify trust based on non-selfregarding motivations, and to differentiate this from the 'weak trust' based on reputation and financial incentives, which is found in the models of economists. Strong trustworthiness, she argued, is more robust than weak trustworthiness, in the face of the difficulties described above. Actors who are not entirely self-interested are less likely to exploit incomplete contracts, or to conceal information, or to act in an untrustworthy way because of the possibility that trust might break down in the future.

Papers in Morris and Vines (2014) took their lead from this argument, using the idea of 'framing'. That book suggested that many of the difficulties which have emerged in the financial sector could be avoided if those working in the financial sector came to frame their activities as ones in which what mattered to them was the value of what they provided to their clients, rather than their own financial return. There were careful discussions of what would be achieved if this were to happen. But it was rightly argued, in response to that book, that not all of those who work in the financial system have such motivations. This paper suggests that good behaviour by those with such motivations will be copied by others. As a result, such behaviour can become embedded in norms of behaviour which have regard for the well-being of customers and clients.

\section{THE RELEVANCE OF NORMS}

Norms are patterns of behaviour that can be self-enforcing within a group: everyone conforms, everyone is expected to conform, and everyone wants to conform when they expect everyone else to conform. Norms are familiar: for instance about the way 
that we tip, or do not tip, in restaurants. What each individual chooses to do depends, not just on his or her motivations, but in part on what is done by others.

We use the word 'norm' in a particular manner, one which follows Young (2015) and Binmore (2006) and understands a social norm to be a pattern or regularity in behaviour that is self-enforcing within a group. This is the conception of norm which is normally used by social scientists when, for example, discussing standards and whether they are met or not. This usage is consistent with the usage in evolutionary models (e.g., Young 2015). Norms can be good or bad. In such an evolutionary picture, one reason for setting a standard is to change the norm from a bad equilibrium to a good equilibrium. The way in which we use the word norm does not address the idea of obligation - the idea that a social norm is a standard of behaviour or conduct shared by a social group and taken to be authoritative or obligatory for them by the majority of the members of the group (Anderson 2000). Norms of the kind that we describe can be sustained in many different ways, including the desire to coordinate, fear of being sanctioned, signalling membership in a group, or simply following the lead of others (Young 2015). In the present paper we focus entirely on the last of these mechanisms, although other mechanisms may well be at work in the situations which we describe. In other words, the effect of conforming may be to make trustworthy behaviour the norm, even although many individuals might, if they were not partly following the behaviour of others, act in an untrustworthy manner. The fact that we suppose decisions by individuals to be partly influenced by the behaviour of others is what takes our approach to trustworthy behaviour beyond the analysis of otherregarding motivations that we described above.

It is widely understood that, when each individual is also influenced in his or her choice by what is chosen by others, then more than one norm may emerge. In other words, there may be more than one stable situation, or 'equilibrium' (Young 2015). The possibility of such self-supporting outcomes depends on the fact that, when any one individual acts, he or she influences the behaviour of other people. When a small proportion of people choose to act in a trustworthy manner, the effect of these choices dissipates, leading to a change in the behaviour of few, if any, others. But the more people who choose to be trustworthy, the larger the number of others who are induced to follow. This happens in a more than proportional manner: the behaviour of those who follow is influenced not only by those who choose to be trustworthy but also by the behaviour of others who are being induced to follow. ${ }^{1}$ In technical terms, there is a 'non-linearity'. Beyond a certain point, the behaviour of the group can 'tip' into an outcome in which trustworthy behaviour becomes the norm (Susskind 2014).

\footnotetext{
${ }^{1}$ This mechanism is explained in Young (2015).
} 
As applied to our case, individuals within a financial firm, or the firm as a whole, who would, on their own, choose to act in an untrustworthy manner, might, as a result of paying attention to the behaviour of others, decide to act in a trustworthy manner. This is particularly likely to be the case if that actor is located within a firm in which others are acting in a trustworthy manner. It should be the aim of policy to support this outcome, rather than the opposite one in which untrustworthy behaviour becomes the self-supporting norm.

\section{NORMS AND FINANCIAL REFORM}

A policy of financial reform which aims to give rise to an outcome with a selfsupporting trustworthy norm can be made to work in a number of different ways.

A policy of financial reform can be designed so as to lead some actors in the financial sector to change their motivations, by changing the way in which these actors frame what they do. As already set out in the papers in Morris and Vines (2014), individuals can come to see their activities as ones in which what matters to them is not just their own financial returns, but also the value of what they provide to their clients. As a result, these actors, and the firms within which they are located, can change their behaviour to become more trustworthy. But - and this is the point of focusing on norms - that will have effects on other actors in the financial sector as well, even if those other actors do not change the way they frame the activity. If left to themselves, the motivations of these other actors lead them to act in an untrustworthy way. Nevertheless, it can be the case that, because of the behaviour of other-regarding actors, trustworthy behaviour becomes the norm.

The behaviour of such conformist actors is not driven by the interests of clients. But it can be sustainable because it tracks the behaviour of the other-regarding actors. That is to say, a change in framing by some may, of itself, shift the norm-if it changes the behaviour of enough others. To what extent this might happen is an empirical matter. We see an investigation of this question as an important topic for future research.

Alternatively, a similar effect could be achieved with a policy of financial reform that is designed to work by setting out standards of trustworthy behaviour. In addition, it might be possible to directly intervene to bring about changes in the work practices of at least some people, in a manner that is informed by psychology and behavioural economics, in order to cause these people to act in a more trustworthy manner. In both of these cases, as with that of changing motivations, inducing some actors to behave in a more trustworthy way can have effects on other actors, even if they themselves do not respond to the standard or to the behavioural interventions; 
it may be that trustworthy behaviour becomes the norm. Those whose behaviour is conformist are not guided by the standard or directly affected by the behavioural intervention. But acting in accord with the standard or the intervention may be sustainable because it tracks the behaviour of the first set of actors. That is to say, the setting of the standard or the implementation of the behavioural intervention may, of itself, shift the norm - if it changes the behaviour of enough actors. To what extent this might happen is also an empirical matter. An investigation of this question is also an important further topic for future research.

Before we can use policy to bring about change in norms, we need to investigate what behaviours are needed in order for financial institutions to be trustworthy. A financial institution has multiple corporate purposes that include offering a wide range of financial services to many types of client or customer (O'Neill 2016). We will argue that the different activities require different norms for trustworthy behaviour and that these need to be sustained by motivations, or by standards, in different kinds of ways. At the end of the next section we will describe the kind of research which is needed to better understand what these norms might be.

\section{FUNCTIONS AND NORMS WITHIN A FINANCIAL FIRM: THE RESEARCH THAT IS NEEDED}

In this section we discuss the failures which have emerged in financial firms from following the traditional approach of using financial incentives to ensure that behavioural outcomes are trustworthy for customers. We describe the kind of research which will be required in order to understand what norms need to be established in order that this might change.

\section{Mortgage lenders and advisors}

In the period before the global financial crisis, those who worked as mortgage lenders were remunerated according to the number of mortgages sold. This enabled those who provided mortgages to frame their circumstances as being ones in which only their own interests were of concern. That led to norms of behaviour that fell short of professional standards regarding how customers ought to be treated.

The chain of events in the US was the following. House prices were rising which enabled lenders to provide more mortgages for sub-prime borrowers with poor credit histories - even although many of these people could not afford even the low rates of interest ruling at the time (Shiller 2013). The mortgages initially had low 'teaser' rates of interest, and were therefore initially affordable for poorer borrowers. But a 
requirement for a much higher interest rate after an initial period was built in; averaged over the life of the mortgage, the returns would then be high. It was expected that poorer borrowers would nevertheless be able to pay the higher interest charges in the future, by increasing the size of the mortgage at that later time-when houses would be more valuable - by accessing this higher capital value to pay the higher interest obligations. Regulators could have prevented this high-risk financial engineering but they did not. ${ }^{2}$ Banks were able to increase the yield from this activity by funding increases in their lending, not by increasing capital but by leveraging, thereby increasing the return on a bank's capital by exploiting small gaps between the returns on lending and the cost of borrowing. ${ }^{3}$ Banks were then able to securitise mortgage loans and to sell the securities on to unregulated financial institutions which were not required to hold capital in support of this lending. In the end, since mortgage originators did not intend to hold onto the mortgages themselves and bear the risk of doing so, they did not need to carefully evaluate the riskiness of the mortgages which they created, and they did not do so.

This was an untrustworthy outcome; employees pursued their own returns but showed an inadequate concern as to whether the mortgages served clients' needs. When interest rates rose, there was large and widespread exposure to mortgages that failed, producing bad outcomes for borrowers. Financial instability was created; it became impossible to roll over the leveraged funding; this was the trigger which led to the global financial crisis. ${ }^{4}$

Detailed circumstances were different in the UK; nevertheless, 'it was also clear that the existing regulatory framework had been ineffective in constraining particularly risky lending and unaffordable borrowing' (FSA 2010: 5). Evidence in the ongoing Royal Commission into Banking in Australia has revealed continuing problems of this kind in that country (Royal Commission into Misconduct in the Banking, Superannuation and Financial Services Industry 2018).

In the UK, action has been taken to address these problems. The UK regulator the Financial Conduct Authority (FCA), has established a set of standards for 'responsible lending' rules following a Mortgage Market Review. These rules: prevent the self-certification of mortgages; require a credible strategy for interest-only mortgages; insist that lenders stress-test affordability; and require that those obtaining a mortgage

\footnotetext{
${ }^{2}$ The federal government guaranteed Fannie Mae and Freddie Mac, two private-sector companies which for many years insured a large proportion of all mortgages in the US for very low premiums, and so subsidised an activity which was risky for lenders and dangerous for borrowers.

${ }^{3}$ This way of increasing return of course increased the vulnerability of banks to the credit risk described in the preceding paragraph.

${ }^{4}$ Macroprudential policy has been introduced to address the problem of system-wide financial stability; we do not discuss that major issue here.
} 
are advised by qualified staff. And there is also now a separation between sales and advice.

Given the introduction of these new standards, will they establish new norms of responsible behaviour towards customers? The answer to this question is not yet clear, since this new regime is discretionary, and has not yet been tested. The FCA has required that lenders carry out stress tests using market expectations and taking account of recommendations by the Financial Policy Committee of the Bank of England (FCA 2016b). But the FCA is not prescriptive about how banks and building societies should handle maximum amounts lent, or the stress tests on customer finances in the face of higher interest rates; practice varies widely. Second, a norm of behaviour appears necessary for mortgage advice. The academic literature on mortgage lending has concentrated on the literacy of those seeking mortgage advice (Cox et al. 2015, Disney \& Gathergood 2013). But such an approach places heavy responsibility on the shoulders of the borrower, and not enough on advisors, who possess more knowledge. A trustworthy advisor needs to take the time to help clients understand the potential outcomes of different mortgage profiles. This reveals a need for 'intelligent information provision' (O'Neill 2006) on the part of advisors, something which needs to become part of the new norm of behviour.

It is important that these new standards are widely adopted and become the norm. In those circumstances it will become unattractive for providers to undercut these standards, so that the standard becomes self-reinforcing. That will prevent the emergence of the kind of unaffordable lending which occurred before the crisis. Ideally, that will become the case without disciplinary action by the FCA being necessary.

\section{Fund managers}

The traditional economic approach of using financial incentives to encourage trustworthy outcomes was also inadequate in the case of fund managers. That was justified by academic work on the principal-agent problem, on the grounds that performance bonuses align the interests of managers and shareholders. But the interests of fund managers clearly encourage these actors to seek short-term benefit at the expense of the long-term interests of their clients (Stracca 2006), which happens as a result of tying bonuses to performance (Shiller 2013). Failure emerged in two particular ways, both to do with moral hazard.

First, financial products make it possible for a manager to create the appearance of superior performance over long periods of time. It is possible for a manager to use derivatives to increase investors' normal rewards, and his or her own reward, at the same time as creating tail risks for the investor; this can be achieved by purchasing a derivative which regularly pays out a fee, in exchange for the occasional right to seize 
the entire asset (Noe \& Young 2014). Compensation schemes with bonuses usually have the feature that in the periods when the client makes a good return, the manager obtains a bonus. However, when the asset is seized by the person who issued the derivative, the investor loses everything, but the fund manager merely fails to get his or her bonus. It obviously benefits a fund manager to seek out products which create a good return in this manner, even if doing so creates tail risks. Performance contracts can guard against such untrustworthy behaviour only if they enforce very large losses on managers in bad times - for example, bankruptcy or imprisonment-but managers do not often accept that possibility. Since such a set-up will normally yield good returns for the investor, it will take many years before investors can determine with any degree of confidence whether a fund manager who is generating good returns is actually trustworthy, or is instead acting in a dishonest way by creating tail risks. In the lead-up to the sub-prime crisis in the US, it appears that many fund managers were effectively concealing fat tails in the returns on assets (Shiller 2013). Sometimes this was due to intentional deception, designed to take advantage of clients, as in the Abacus case (O’Brien 2012).

Second, the complexity of new products and the size of modern financial institutions make it difficult and costly for investors to monitor risky investments directly. A self-interested and selfish manager cannot be made to do this by means of bonuses in his or her compensation scheme. This is also because such bonus schemes do not contain sufficiently large penalties in the event of a catastrophe. It may be true that, if managers undertake monitoring on behalf of their clients, they will reduce the probability of such a catastrophe. But managers will face nothing worse than a nobonus outcome if a catastrophe occurs. And there is only a very low probability of this happening, even if they do not carry out the necessary monitoring. As a result, they must be paid a very high bonus if they are to find it worthwhile to incur the cost of risk monitoring, merely in order to slightly reduce the (small) probability of earning no bonus. Instead, they will find it more attractive to act dishonestly and merely pretend to monitor, knowing that things will go well most of the time. It is clear that performance contracts induce managers to undertake monitoring only if they enforce very large losses on managers in bad times. Since the probability of catastrophe is low, it will take many years before investors discover that such monitoring is not in fact happening.

It is clear that the pursuit of reputation will not —of itself — be sufficient to prevent such outcomes, since the time scales are long. Research is needed on the way in which concern for the well-being of customers might be brought to bear in influencing the choice of assets, and about how performance of assets is monitored. A norm of behaviour is needed in which fund managers reveal more, in detail, about how risky assets are chosen for clients and about how these risky assets are monitored. 
Behavioural norms in which there is mere disclosure of information by advisors will not be sufficient to meet this need (O'Neill 2006). Mere disclosure of information is not 'communication'; communication fails if the audience cannot understand and assess what is communicated and assess its credibility. Something more than this is needed.

\section{Insurers}

The traditional economic approach of contracts and monitoring to secure trustworthiness was, once again, inadequate in the case of the provision of insurance. The appropriate level of insurance for customers depends on their reserves and ability to bear adverse events, and on their appetite for risk. It is necessary to develop norms of behaviour around sales of insurance to secure robust trustworthiness in this sale, across a wide range of circumstances.

The case of Payments Protection Insurance (PPI), or credit protection insurance, is useful to illustrate what went wrong and why norms are needed. PPI is a product that enables consumers to ensure the repayment of credit if the borrower experiences circumstances that prevent them from earning income to service the debt (Georgosouli 2014, McConnell \& Blacker 2012). As we now know, in the UK, PPI was widely missold by banks and other credit providers as an add-on to a loan or overdraft product. The sale of such policies was typically encouraged by commissions; some companies developed sales scripts which suggested sales people say only that the loan was 'protected' (de Meza et al. 2010). Such scripts neither mentioned the nature nor the cost of the insurance, so many consumers did not know that they had purchased PPI.

The most obvious problem with PPI misselling was this fraudulent misdescription of products. However, while avoiding fraudulent behaviour is necessary, it is not sufficient. The way PPI was sold encouraged sellers to sell insurance to customers regardless of their need or of their risk appetite, in a situation in which customers were unaware of the costs and benefits of the insurance.

A trustworthy insurer needs to take the time to help the client to understand the potential outcomes of different insurance policies and go through which one best suits the client's ability to bear the cost of adverse events and assesses carefully their appetite for risk. As in the previous cases, there is also a question of how information should be communicated to customers. It is important to make sure that norms of behaviour developed in this context are geared towards enabling the intelligent non-specialist customer to use his or her own judgement about whether to take out insurance. As things stand, the US Consumer Financial Protection Bureau (CFPB) and the UK Money Advice Service aim to improve customer financial literacy, and the CFPB allocates the responsibility for this improvement to firms (McConnell \& 
Blacker 2012). However, it is also important to increase literacy without placing an unreasonable burden on the customer. Financial institutions have an obligation to ensure the kind of intelligent information provision described earlier. In this area, norms of communication make a difference to sustaining trustworthiness. It is clear that certain such norms have already begun to change; the way that those who sold PPI acted is no longer widely acceptable.

\section{Traders}

What went wrong amongst traders, both before and after the financial crisis, was not to do with a lack of concern for the well-being of clients, but was instead a result of fraud.

Traders act purely in their own self-interest and are not concerned with the interests of others. In particular, propriety traders trade on their own account in order to gain instantaneous rewards from short-run price movements. In doing this they engage in risk arbitrage: they profit from price discrepancies across markets. Their self-interested behaviour plays a useful role in markets where their actions ensure that the prices in markets reflect value (Shiller 2013).

Unlike the other front-line employees that we have analysed, norms that show concern for others are inappropriate for traders. Rather, traders have a narrowly defined set of obligations with which they are expected to comply. The task for traders is to avoid fraud.

The LIBOR and foreign exchange market scandals resulted from fraudulent behaviour. The London Inter-Bank Offered Rate (LIBOR) is a benchmark short-term interest rate that is calculated from submissions by a number of leading banks, which estimate their costs of borrowing on the inter-bank market. Banks misreported what it cost them to borrow, in an ongoing manner. Many banks held large financial positions that were indexed to LIBOR, so that the numbers submitted directly impacted the profits of traders. Although submitters were supposed to be separated from traders by Chinese walls, it was common practice for traders and submitters to collude over the rate report (McConnell 2013). ${ }^{5}$ In itself, the fact that traders were able to record their dealings shows that the practice had become institutionalised. It seems possible that management knew about and even condoned false reporting (Nelson 2016).

\footnotetext{
${ }^{5}$ The management of banks also faced a conflict of interests. First, a lower submission implied a greater credit-worthiness, so a bank had incentives to report too low a rate in order to protect its reputation. The Commodity Futures Trading Commission uncovered a management directive to 'keep LIBOR submissions lower to protect Barclays' reputation' (McConnell 2013).
} 
Correcting this corrupt behaviour will not require the behaviour of traders to be underpinned by a concern for the well-being of others. A successful process of financial reform will still leave traders as self-interested actors playing a valuable role in markets. This has significant implications for the reform of the governance of financial firms. Nevertheless, norms were important in what happened; it became a common practice to submit misleading reports, behaviour which was supported by cooperation amongst the traders.

\section{Implications for research}

We already know from experimental research that some environments permit people to be dishonest. And there is evidence that a banking frame can lead to more dishonest behaviour by bank employees. For example, a 2014 study undertook a behavioural experiment with bank employees and employees in other industries. The study found that the employees of a large international bank on average behaved honestly in a control condition. However, when their professional identity as a bank employee was rendered salient in the experiment, a significant proportion of them acted dishonestly (Cohn et al. 2014). But there is, as yet, little work on the reverse question: how is it possible to encourage people to be honest?

Our discussion above has suggested that two things are necessary, in all of mortgage provision, fund management, and the provision of insurance. The first is that enough actors come to see the importance of acting in a way which has regard to the needs of customers. Second, enough other actors need to follow the first group, to ensure that such behaviour becomes a norm. What is now needed is a detailed study of how this can be made to happen. It will be important to understand the way in which there is something about the culture of financial institutions, including but not confined to the reward structure, that leads people to behave badly, and to propose and test how cultural change might be used to encourage individuals to behave in a more moral manner. Given that we acknowledge that not all individuals will be other-regarding, research about the development of norms in populations that consist of both other-regarding and selfish types is required. Some experimental evidence exists about the development of cooperative norms amongst selfish individuals in the lab (Fehr \& Gintis 2017), but it will be important to apply this to the financial sector in future research.

We have also argued that a norm of intelligent information provision is central to good outcomes in all of these activities. Research is needed into what that norm should be. However, best practice for information provision is not a simple matter because the way that information is presented may influence product choice. People use heuristics in decision making, which may lead to 'biases', or systematic errors in 
judging the probability of outcomes or in predicting how one will feel about outcomes if they occur (Baron 2014). Benartzi and Thaler (2007) discuss how this can affect individual saving for retirement and Kahneman and Riepe (1998) apply this to financial advice. Work is needed on how this affects the way that information should be provided to purchasers and consumers of financial products.

In contrast, we have argued that the activity of traders can be, and is, selfish. But there too there is need for a norm of information provision-information needs to be truthfully provided. In our discussion of other roles within the bank, we argued that what is needed is other-regarding rather than selfish motivations in order to get better outcomes. Here what is required is the prevention of illegal outcomes. Preventing fraud is about enforcing the law; other-regarding motivations are not the relevant ones. Nevertheless, one might be able to use the apparatus of norms to tell a story which is similar to that told in relation to other roles, one in which a small group of people who are motivated to obey the law can galvanise a norm of good behaviour.

\section{GOVERNANCE OF FINANCIAL FIRMS: THE RESEARCH WHICH IS NEEDED}

The classic analysis of corporate governance - and of how the board of a company should behave-is the principal-agent model (Jensen \& Meckling 1976, Shleifer \& Vishny 1997). Underpinning this model is the idea that shareholders are those who bear the risk concerning whether a firm does well or badly, and that shareholders should be rewarded for bearing this risk. Analysis of this model has been used to show that shareholder value can be maximised through an appropriate use of financial incentives for the board and for the firm's employees (Ross 1973). This same analysis has been used to suggest that a firm which seeks to maximise shareholder value through the use of financial incentives will build a reputation for acting in a trustworthy manner. Doing so, it is argued, will enable the firm to deliver services to clients in a way which would not be possible if these clients did not trust it.

But we have shown above that, in the provision of mortgages, fund management services and insurance, the use of financial incentives is - on its own-unlikely to bring about a trustworthy outcome. The difficulty which we have identified is that employees may act in a way which increases their short-run return, at the expense of their customers and clients. The task facing a board of a company and its management is to take into account what modes of behaviour - what norms - are necessary for those who work for the firm to be strongly trustworthy in relation to the firm's clients, and to lead the firm in a way designed to help to bring about this behaviour. 
This has three implications for the behaviour of the board of a firm, and for its management.

First, this trustworthy behaviour will only become the norm if it is underpinned by a board of the company which encourages, and leads, such behaviour. This will be the case if the board of directors sees itself as having as an obligation to ensure the longer term prosperity of the firm. (Blair \& Stout 1999, Clark 1986). It is well known that the type of shareholder a firm has influences the type of action that the board and senior managers take (Ravasi \& Zattoni 2006, Shleifer \& Vishny 1986, Zattoni 2011, Zeitoun $\&$ Pamini 2015). A firm may have 'transactional shareholders', concerned only about short-term returns (Strine 2017). But a firm may have shareholders who are 'relational owners', ones who are concerned about the long-term relationships with customers and clients that its employees need to form, in the long-term interests of the firm. Boards of trustworthy companies will need to find ways of defending themselves against the pressure exerted by transactional shareholders, so as to lead and encourage the behaviour of trustworthy employees. Efforts are being made to do this. (See, for example, Barclays Bank 2018.) Research is needed to see how successful these efforts are.

Second, the norms of behaviour in client-facing parts of a financial firm need to be shielded from the norms of behaviour amongst traders, since they differ from the norms of behaviour for traders. The relationship between traders and those from whom they buy these products need not be one of strong trustworthiness. Instead, it is merely necessary that such traders act so as to avoid fraud. Providing that fraud is avoided, such traders may act in a purely self-regarding manner.

Yet, in many universal banks, traders and client-facing staff work alongside each other. The interactions between traders and these other employees are critical, since self-regarding motivations can spread throughout a firm if not carefully contained, undermining the appropriate norms of behaviour. We have argued that if, in the client-facing part of a firm, there are enough actors who have regard for the interests of others, or who follow standards, then this will cause other actors to follow their behaviour, leading to a self-supporting outcome of trustworthy behaviour. But if the self-regarding norms of traders spread, then that jeopardises the underpinning of strongly trustworthy behaviour, undermining the non-self-regarding obligations of enough actors, leading to a norm of untrustworthy behaviour.

This may well encourage mortgage providers, fund managers, and insurers to act in ways that disadvantage their customers. We have argued that norms of behaviour are established in part by the copying of others; it may be that the kinds of behaviour carried out by traders come to be copied by others, leading to untrustworthy behaviour. This shows just how difficult it will be for management to ensure adequate norms of behaviour in a firm with many different purposes. There is a significant research question in determining how this might be prevented. 
This need for differing norms in different parts of financial firms creates an issue for those who have argued in favour of ethical leadership in firms (Nelson 2016). It has been argued that the board and senior managers need to act as ethical leaders in firms, in order to establish appropriate norms across a firm. It has been found that integrity and ethical stewardship are important determinants of trust in leaders, both proximal supervisors and distal top managers (Fulmer \& Gelfand 2012). Ethical stewardship has been defined as the honouring of duties owed to employees, stakeholders, and society in the pursuit of long-term wealth creation (Caldwell et al. 2008) - the pursuit of trustworthiness which we have been discussing in this paper will be part of that process. It is argued that trust in leaders is increased when leaders and subordinates share the same values (Fulmer \& Gelfand 2012). But, as we have been arguing, the values of traders will necessarily differ from those in other parts of the firm, so leaders cannot share the values of all employees. It would be a problem if the client-facing parts of the firm perceive the values of the leadership as in alignment with those of the traders. In particular, this may be a problem for independent directors of a firm, if they represent the interests of transactional shareholders who have short-lasting tenure or remuneration geared to short-term results (Kang \& Kroll 2013). The board and the management of a firm need to endorse the norms that are appropriate for the areas in which the parts of the firm operate.

However, if these different parts of a firm need to have different kinds of norms, then this situation will be demanding for management to bring about. Understanding how this might be brought about requires a much more detailed anthropology of banking than is currently available. This will require detailed observational study of the units involved. One important way to carry out this research will involve analysing the behaviour of banks that functioned well in the run-up to and after the global financial crisis, and comparing that with the behaviour of banks that did not. This approach will enable us to determine the extent to which a different form of corporate governance enabled better outcomes, and the role which management structure played in bringing about these good outcomes. This sort of corporate anthropology is also an important basis for research using the abstract methods of behavioural and evolutionary economics. These disciplines use models that abstract the important features of interactions. But knowing about the interactions in more detail is a prelude to being able to provide a relevant model. This can open up promising avenues of research: for instance, it seems likely that research into the role of leadership could benefit from study of behaviour in asymmetrical games, where the players move diachronically and have different pay-offs.

Third, in universal banks, and other financial institutions that carry out a range of services, it may be that fund managers, insurers, and the providers of insurance need to protect their clients from the behaviour of traders within the firm. 
One example reveals the difficulties involved. In the well-known Abacus case, assets which appeared likely to fall in price were packaged together by analysts acting for Goldman Sachs. Traders shorted the resulting bundle of securities products, intending to make money when the price fell (O'Brien 2012). At the same time, the client-facing part of Goldman Sachs, in which individuals provided fund management services to clients, sold these assets to their clients. The clients relied on the superior knowledge and reputation of Goldman Sachs to select assets for them, but the fund managers in Goldman Sachs did not protect their clients from the risks associated with these assets. Trustworthy behaviour by the client-facing part of the organisation would have required that this part of the firm not sell such products to its clients, which had been created in another part of the firm.

This activity was untrustworthy not because fund managers should have used their superior knowledge, on which their reputation depended, to ensure that they did not sell such products to clients. This is because risky products of this kind are regularly created in markets and fund managers inevitably make mistakes in failing to identify them when selecting assets for their clients to buy. We do not make such a competencebased argument.

Instead, we say that trustworthy behaviour by the client-facing part of the organisation would have required that this part of the firm not to sell such products to its clients, because they had been created by employees working for Goldman Sachs. In this article we have argued that trustworthy fund-management behaviour needs to be built on a concern for the well-being of customers. We now argue, additionally, that if a firm employing fund managers - in this case Goldman Sachs - is to show concern for the well-being of customers, then that will require that fund managers be able to protect customers from deleterious actions of those working for other parts of the firm.

One response to this problem is the one offered by Goldman Sachs in the Abacus case - the Chinese wall defence. This defence argued that fund managers were unaware that the relevant assets were likely to fall in price, because of the existence of a Chinese wall within the firm. Fund managers had not themselves constructed the bad assets which were being sold to clients - it was said - and the existence of a Chinese wall meant that the fund managers were unaware that the assets were ones which were likely to fall in price.

However, the CEO and the board have oversight of both the fund-management and the trading divisions. There appears to be a conflict between overseeing fund managers who are required to act in a trustworthy way towards clients and overseeing the activity of traders who create bad products that may be sold to clients by fund managers. This conflict can be said to arise because of an analogy with a person. An individual person could not be said to be trustworthy in relation to a particular contract if that person - at the same time as signing the contract - deliberately undertook action which would damage outcomes for the recipient of that contract. 
This kind of problem creates a demanding challenge for the management of a firm, and for the board. It becomes the task of management, and the board, to identify actions of any one part of a firm that are likely to damage the well-being of clients of any other part of the firm, and to advise the client-facing parts of the firm-here the fund managers - to behave in ways which insulate their clients from that first set of actions. This will require a reporting structure and decision-making structure which make this possible. It will be hard for senior management to do this and for the board to ensure that this is done, but it will be essential. This creates a further task for the ethical leadership of a firm.

How this can be brought about will require a continuation and extension of the work on ethics management which has already begun (de Bruin 2014, 2015). One response, which has been adopted by Barclays and by banks in the Netherlands, is to require that executives attend ethics education courses (de Bruin 2014, 2015). However, we caution against this approach, at least in the absence of evidence showing that it will be successful. We note that evidence from other sectors, such as public health, shows that information and training alone are not enough to change behaviour (Marteau 2018, Webb \& Sheeran 2006). We also know that familiarity with moral theories does not improve behaviour: research has shown that professors specialising in ethics do not behave more ethically than other professors (Schwitzgebel \& Rust 2014). Instead, we think a more promising route is to turn to behavioural science and to draw on evidence about the ways in which we can change behaviour, sometimes called the 'behavioural insights' approach (Dolan et al. 2012). It is important to move towards 'behavioural management' and 'behavioural organisational science'.

\section{CONCLUSION}

We have examined what patterns of behaviour or norms might exist in a financial institution that is acting in a strongly trustworthy manner.

We have argued that the kinds of norms that are required for trustworthiness differ across the different kinds of activities that take place within a financial sector firm. We have identified a number of actors and have asked what is necessary for their activity to be trustworthy: we have considered shareholders, the board, mortgage lenders, fund managers, insurers, and traders. In doing this we have described how the patterns of behaviour, or norms, that are trustworthy differ in each of these activities.

We have shown how-in all of the activities in financial firms that we have considered, other than trading - a concern for the well-being of others is necessary in order to sustain patterns of behaviour that are trustworthy. We have argued that such activities are likely to be provided in an untrustworthy manner if the choices made by those working within the firms are framed in a manner that is entirely self-regarding. 
We have also argued that, if those working in these activities frame their activity in terms of concern for the well-being of clients, then that might lead to the provision of the service in a more trustworthy manner. However, in addition-and this is the point of focusing on norms - the behaviour of those who show concern for the wellbeing of clients may well have effects on the self-regarding actors as well, even if those self-regarding actors do not change the way they frame the activity. If left to themselves, the motivations of these self-regarding actors may lead them to act in an untrustworthy way. Nevertheless, it may be that, because of the influence of those who show concern for the well-being of clients, trustworthy behaviour becomes the norm. We have described the kinds of research which are necessary to give greater support to these claims.

We have argued that trustworthy trading activity is different. Trading does not need to be - and cannot be - supported by actors whose motivations relate to the well-being of clients. Trading is a self-interested activity; it is not concerned with achieving 'fair' outcomes. Nevertheless, standards are important; we have argued that fraudulent behaviour needs to be avoided and trading activity can only be trustworthy if this happens.

Our work suggests that there is a deep problem for the governance of financial firms. The board of such a firm has to confront the fact that trading is a self-interested activity, whereas the norms of behaviour in other parts of a financial firm need to be underpinned by at least some individuals showing concern for the well-being of clients. There is a need to prevent the self-interested motivations of traders from infecting the motivations of those in other parts of the institution. Even if this does not happen, there is a need to protect the customers in the client-facing part of an institution from those activities of traders that might damage their well-being. Research is necessary into how these two necessary outcomes could be achieved.

One implication of this is that a clear firm structure and set of trust relations is a prerequisite for achieving trustworthiness of financial institutions. This has implications for the proposed ring fencing of banks. This ring fencing has been set up to separate banks' retail operations from their riskier investment banking activities (Independent Commission on Banking 2011). But ring fencing should also separate the trading departments, in which the employees are necessarily profit-seeking and self-interested, from the other financial activities that we have analysed. The more complex and ambiguous the structure of a firm, the harder this ring fencing will be to achieve. It will also be all the more important. There is a clear challenge to those working on ethics management in finance, and ethical leadership, to determine how this might be achieved. 


\section{Acknowledgements}

We are grateful to two anonymous referees for helpful comments, and are glad to acknowledge financial support from the British Academy's Research Project on the Future of the Corporation.

\section{REFERENCES}

Anderson, E. (2000), 'Beyond Homo Economicus: New Developments in Theories of Social Norms', Philosophy and Public Affairs, 29: 170-200. https://doi.org/10.1111/j.1088-4963.2000.00170.x

Baier, A. (1986), 'Trust and Antitrust', Ethics, 96(2): 231-60. https://doi.org/10.1086/292745

Barclays Bank (2013), 'Salz Review: An Independent Review of Barclays’ Business Practices'. https://online.wsj.com/public/resources/documents/SalzReview04032013.pdf [accessed 9August 2018].

Barclays Bank (2018), 'Performance Measures'. https://www.home.barclays/about-barclays/performance-measures.html [accessed 5 November 2018].

Baron, J. (2014), 'Heuristics and Biases', in E. Zamir \& D. Teichman (eds) The Oxford Handbook of Behavioural Economics and the Law (Oxford, Oxford University Press), 3-27.

Benartzi, S. \& Thaler, R. (2007), 'Heuristics and Biases in Retirement Savings Behaviour', Journal of Economic Perspectives, 21(3): 81-104. https://doi.org/10.1257/jep.21.3.81

Binmore, K. (2006), 'Why Do People Cooperate?', Politics, Philosophy and Economics, 5(1): 81-96. https://doi.org/10.1177/1470594X06060620

Blair, M. M. \& Stout, L. A. (1999), 'A Team Production Theory of Corporate Law', Virginia Law Review, 85, 247-328. https://doi.org/10.2307/1073662

Caldwell, C., Hayes, L. A., Bernal, P. \& Karri, R. (2008), 'Ethical Stewardship-Implications for Leadership and Trust', Journal of Business Ethics, 78(1-2), 153-64. https://doi.org/10.1007/s10551-006-9320-1

Clark, R. C. (1986), Corporate Law (Alphen aan den Rijn, Wolters Kluwer).

Cohn, A., Fehr, E. \& Marechal, A. (2014), 'Business Culture and Dishonesty in the Banking Industry', Nature, 516: 86-9. https://doi.org/10.1038/nature13977

Cox, R., Brounen, D. \& Neuteboom, P. (2015), 'Financial Literacy, Risk Aversion and Choice of Mortgage Type by Households', The Journal of Real Estate Finance and Economics, 50(1): 74-112. https://doi.org/10.1007/s11146-013-9453-9

de Bruin, B. (2014), 'Ethics Management in Banking and Finance', in N. Morris \& D. Vines (eds) Capital Failure: Rebuilding Trust in Financial Services (Oxford: Oxford University Press), 255-76. https://doi.org/10.1093/acprof:oso/9780198712220.003.0012

de Bruin, B. (2015), Ethics and the Global Financial Crisis (Cambridge, Cambridge University Press). https://doi.org/10.1017/CBO9781139237093

Disney, R. \& Gathergood, J. (2013), 'Financial Literacy and Consumer Credit Portfolios', Journal of Banking and Finance, 37: 2246-54. https://doi.org/10.1016/j.jbankfin.2013.01.013

De Meza, D., Irlenbusch, B. \& Reyniers, D. (2010), 'Disclosure, Trust and Persuasion in Insurance Markets', discussion paper 5060, Forschungsinstitut zur Zukunft der Arbeit, Bonn.

Dolan, P., Hallsworth, M., Halpern, D., King, D., Metcalfe, R. \& Vlaev, I. (2012), 'Influencing Behaviour: The Mindspace Way', Journal of Economic Psychology, 33(1): 264-77.

https://doi.org/10.1016/j.joep.2011.10.009

Edelman (2018), Edelman Trust Barometer. http://cms.edelman.com/sites/default/files/2018-01/2018_Edelman_Trust_Barometer_Global_ Report_Jan.PDF [accessed 3 February 2018]. 
Fehr, E. \& Gintis, H. (2007), 'Human Motivation and Social Cooperation: Experimental and Analytical Foundations', Annual Review of Sociology, 33: 43-64. https://doi.org/10.1146/annurev.soc.33.040406.131812

FSA (2010), 'Mortgage Market Review: Responsible Lending', Financial Services Authority, July. https://www.fca.org.uk/publication/consultation/fsa-cp10-16.pdf [accessed 18 September 2018].

FSA (2016a), 'Interest Rate Stress Test', Financial Services Authority. https://www.fca.org.uk/firms/interest-rate-stress-test

FSA (2016b), 'Embedding the Mortgage Market Review: Responsible Lending Review', Financial Services Authority.

https://www.fca.org.uk/publication/thematic-reviews/tr16-04.pdf [accessed 1 November 2018].

FSA (2018), 'Transforming Culture in Financial Services', discussion paper 2, March, Financial Conduct Authority. https://www.fca.org.uk/publication/discussion/dp18-02.pdf [accessed 9 August 2018].

Fulmer, C. A. \& Gelfand, M. J. (2012), 'At What Level (and in Whom) We Trust: Trust Across Multiple Organizational Levels', Journal of Management, 38: 1167-230. https://doi.org/10.1177/0149206312439327

G30 (2015), 'Banking Conduct and Culture'. http://group30.org/images/uploads/publications/G30_BankingConductandCulture.pdf [accessed 9August 2018].

Georgosouli, A. (2014), 'Payment Protection Insurance (PPI) Misselling: Some Lessons from the UK', Connecticut Insurance Law Journal, 21: 261-88.

Gold, N. (2014), 'Trustworthiness and Motivations', in N. Morris \& D. Vines (eds.), Capital Failure: Rebuilding Trust in Financial Services (Oxford: Oxford University Press), 129-53. https://doi.org/10.1093/acprof:oso/9780198712220.003.0006

Hollis, M. (1998), Trust Within Reason (Cambridge, Cambridge University Press). https://doi.org/10.1017/CBO9780511612244

Holton, R. (1994), 'Deciding to Trust, Coming to Believe', Australasian Journal of Philosophy, 72(1): 63-76. https://doi.org/10.1080/00048409412345881

House of Lords, House of Commons (2013), 'Changing Banking for Good: Report of the Parliamentary Commission on Banking Standards'. https://www.parliament.uk/documents/banking-commission/Banking-final-report-volume-i.pdf

Independent Commission on Banking (2011), Final Recommendations. http://webarchive.nationalarchives.gov.uk/20131003105424/https:/hmt-sanctions.s3.amazonaws.com/ icb $\% 20$ final $\% 20$ report $/$ icb $\% 2520$ final $\% 2520$ report $\% 5$ B $1 \% 5$ D.pdf

Ipsos MORI (2017), Ipsos-MORI Veracity Index. https://www.ipsos.com/sites/default/files/ct/news/documents/2017-11/trust-in-professions-veracityindex-2017-slides.pdf [accessed 25 January 2018].

Jaffer, S. Morris, N. \& Vines, D. (2014), 'Why Trustworthiness is Important', in N. Morris \& D. Vines, (eds) Capital Failure: Rebuilding Trust in Financial Services (Oxford, Oxford University Press). https://doi.org/10.1093/acprof:oso/9780198712220.003.0001

Jensen, M. C. \& Meckling, W. H. (1976), 'Theory of the Firm: Managerial Behavior, Agency Costs and Ownership Structure', Journal of Financial Economics, 3: 305-60. https://doi.org/10.1016/0304-405X(76)90026-X

Kahneman, D. \& Riepe, M. W. (1998), 'Aspects of Investor Psychology', Journal of Portfolio Management, 24(4): 52-65. https://doi.org/10.3905/jpm.1998.409643

Kang, E. \& Kroll, M. (2013), 'Deciding Who Will Rule: Examining the Influence of Outside Noncore Directors on Executive Entrenchment', Organization Science, 25: 1662-83. https://doi.org/10.1287/orsc.2013.0874

Mailath, G. J. \& Samuelson, L. (2006), Repeated Games and Reputations: Long-run Relationships (Oxford, Oxford University Press). https://doi.org/10.1093/acprof:oso/9780195300796.001.0001 
Marteau, T. M. (2018), 'Changing Minds About Changing Behaviour', The Lancet, 391(10116): 116-17. https://doi.org/10.1016/S0140-6736(17)33324-X

McConnell, P. (2013), 'Systemic Operational Risk: The LIBOR Manipulation Scandal', The Journal of Operational Risk, 8(3): 59-99. https://doi.org/10.21314/JOP.2013.127

McConnell, P. \& Blacker, K. (2012), 'Systemic Operational Risk: The UK Payment Protection Insurance Scandal', The Journal of Ooperational Risk, 7(1): 79-139.

https://doi.org/10.21314/JOP.2012.104

Morris, N. \& Vines, D. (eds) (2014), Capital Failure: Rebuilding Trust in Financial Services (Oxford, Oxford University Press). https://doi.org/10.1093/acprof:oso/9780198712220.001.0001

Nelson, J. S. (2016), 'The Normalization of Corruption', Journal of Management Inquiry, 25: 1-7.

Noe, T. \& Young, H. P. (2014), 'The Limits to Compensation in the Financial Sector', in N. Morris \& D. Vines (eds) Capital Failure: Rebuilding Trust in Sinancial services (Oxford, Oxford University Press). https://doi.org/10.1093/acprof:oso/9780198712220.003.0003

O'Brien, J. (2012), 'The Façade of Enforcement: Goldman Sachs, Negotiated Prosecution, and the Politics of Blame', in S. Will, S. Handelman \& D. Brotherton (eds) How They Got Away with it: White Collar Criminals and the Financial Meltdown (New York, Columbia University Press), $178-202$.

O’Neill, O. (2002), A Question of Trust: The BBC Reith Lectures 2002 (Cambridge: Cambridge University Press).

O’Neill, O. (2006), 'Transparency and the Ethics of Communication', in Transparency: The Key to Better Governance? C. Hood \& D. Heald (eds) (Oxford, Oxford University Press), 75-90. https://doi.org/10.5871/bacad/9780197263839.003.0005

O’Neill, O. (2016), 'What is Banking For?', remarks by Baroness Onora O’Neill, Federal Reserve Bank of New York, October.

https://www.newyorkfed.org/medialibrary/media/governance-and-culture-reform/ONeill-CultureWorkshop-Remarks-10202016.pdf [accessed 9 August 2018].

Ravasi, D. \& Zattoni, A. (2006), 'Exploring the Political Side of Board Involvement in Strategy: A Study of Mixed-ownership Institutions', Journal of Management Studies, 43: 1671-702. https://doi.org/10.1111/j.1467-6486.2006.00659.x

Ross., S. (1973), 'The Economic Theory of Agency: The Principal's Problem', American Economic Review, Papers and Proceedings, 63(2): 134-9.

Royal Commission into Misconduct in the Banking, Superannuation and Financial Services Industry (2018). https://financialservices.royalcommission.gov.au/Pages/default.aspx

Schwitzgebel, E. \& Rust, J. (2014), 'The Moral Behavior of Ethics Professors: Relationships Among Selfreported Behavior, Expressed Normative Attitude, and Directly Observed Behavior', Philosophical Psychology, 27: 293-327. https://doi.org/10.1080/09515089.2012.727135

Shiller, R. J. (2013), Finance and the Good Society (Princeton, NJ, Princeton University Press). https://doi. org/10.1515/9781400846177

Shleifer, A. \& Vishny, R. W. (1997), 'A Survey of Corporate Governance', Journal of Finance, 52: 737-83. https://doi.org/10.1111/j.1540-6261.1997.tb04820.x

Shleifer, A. \& Vishny, R. W. (1986), 'Large Shareholders and Corporate Control', Journal of Political Economy, 94: 461-88. https://doi.org/10.1086/261385

Stracca, L. (2006), 'Delegated Portfolio Management: A Survey of the Theoretical Literature', Journal of Economic Surveys, 20: 823-48. https://doi.org/10.1111/j.1467-6419.2006.00271.x

Strine, L. E. (2017), 'Corporate Power is Corporate Purpose I: Evidence from my Hometown', Oxford Review of Economic Policy, 33(2): 176-87. https://doi.org/10.1093/oxrep/grx027

Susskind, D. (2014), 'Towards an Economic Theory of Moral Contagion', MPhil thesis, University of Oxford. 
Webb, T. L. \& Sheeran, P. (2006), 'Does Changing Behavioral Intentions Engender Behavior Change? A Meta-analysis of the Experimental Evidence', Psychological Bulletin, 132(2): 249-68. https://doi.org/10.1037/0033-2909.132.2.249

Williamson, O. E. (1993), 'Calculativeness, Trust, and Economic Organization', The Journal of Law and Economics, 36(1, Part 2): 453-86. https://doi.org/10.1086/467284

Young, H. P. (2015), 'The Evolution of Social Norms', Annual Review of Economics, 7: 359-87. https://doi.org/10.1146/annurev-economics-080614-115322

Zattoni, A. (2011), 'Who Should Control a Corporation? Toward a Contingency Stakeholder Model for Allocating Ownership Rights', Journal of Business Ethics, 103: 255-74. https://doi.org/10.1007/s10551-011-0864-3

Zeitoun, H. \& Pamini, P. (2015), 'Corporate Ownership Structure and Top Executives' Prosocial Preferences: The Role of Relational and External Blockholders', Corporate Governance: An International Review, 23: 489-503. https://doi.org/10.1111/corg.12111

Notes on the authors:

Dr Aisling Crean is a philosopher currently working on corporate trustworthiness and teaches on the Master of Public Policy at the Blavatnik School of Government, University of Oxford. She has just completed two British Academy postdoctoral projects on corporate trustworthiness at the Blavatnik School of Government and at the Institute for New Economic Thinking, Oxford Martin School, University of Oxford. Recently, she published 'Do corporations have a duty to be trustworthy?' in the Journal of the British Academy (2018 (this issue)), with Nikolas Kirby and Andrew Kirton. Her interests range from ethics to political philosophy to the history of philosophy, epistemology, and metaphysics. She has also published on David Hume. aisling.crean@bsg.ox.ac.uk

Dr Natalie Gold is a Senior Research Fellow in the Faculty of Philosophy at the University of Oxford, and a Principal Behavioural Insights Advisor at Public Health England. Her work covers many subjects, from philosophy to behavioural science, often in an interdisciplinary manner. From 2011 to 2017 she was Principal Investigator on the European Research Council Grant 'Self-Control and the Person: An Interdisciplinary Account'. She has published on topics including framing, moral judgements and decisions, cooperation and coordination, trustworthiness and finance, behaviour change and nudge, and self-control.

natalie.gold@rocketmail.com

David Vines is Emeritus Professor of Economics and Emeritus Fellow of Balliol College, at Oxford University. He is the Director of the Ethics and Economics Programme at the Institute for New Economic Thinking in the Oxford Martin School, and a Research Fellow of the Centre for Economic Policy Research in London. His research is on financial reform, international macroeconomics, and global economic 
governance. From 2018 to 2012 he was the Research Director of PEGGED, a European Union Framework Seven Research Programme, which examined European Dimensions of Global Economic Governance. His most recent book, written jointly with Peter Temin, is Keynes: Useful Economics for the World Economy (MIT Press, 2014).

david.vines@economics.ox.ac.uk

Annie Williamson is a postgraduate in the Department of Economics at the University of Oxford, and a research economist at Partners in Health Mexico. Her work focusses on the role of motivation in labour markets, particularly in the National Health Service, and the relationship between health care and economic outcomes. She has published on decision making in the context of Brexit trade negotiations, and presented on motivating health service provision and upholding the right to health care in Mexico.

anne.williamson@economics.ox.ac.uk

To cite the article: Aisling Crean, Natalie Gold, David Vines and Annie Williamson (2018), 'Restoring trustworthiness in the financial system: Norms, behaviour, and governance', Journal of the British Academy, 6(s1): 131-155.

DOI https://doi.org/10.5871/jba/006s1.131

This article is licensed under a

Creative Commons Attribution-NonCommercial-NoDerivs 4.0 Unported License.

Journal of the British Academy (ISSN 2052-7217) is published by

The British Academy - the national academy for the humanities and social sciences.

10-11 Carlton House Terrace, London, SW1Y 5AH

www.britishacademy.ac.uk 
